\title{
Barriers to and opportunities for the use of forage tree legumes in smallholder cattle fattening systems in Eastern Indonesia
}

\author{
DEBORA KANA HAU ${ }^{1}$, TANDA PANJAITAN ${ }^{2}$, JACOB NULIK $^{1}$, DAHLANUDDIN $^{3}$ AND \\ ELSKE VAN DE FLIERT ${ }^{4}$
}

${ }^{1}$ Assessment Institute for Agricultural Technology - East Nusa Tenggara, Naibonat, Kupang, NTT, Indonesia. http://ntt.litbang.deptan.go.id/

${ }^{2}$ Assessment Institute for Agricultural Technology - West Nusa Tenggara, Narmada, Lombok Barat, NTB, Indonesia. http://ntb.litbang.deptan.go.id/

${ }^{3}$ Universitas Mataram, Mataram, NTB, Indonesia. www.unram.ac.id/en/

${ }^{4}$ The University of Queensland, St Lucia, Australia. www.uq.edu.au/ccsc

Keywords: Leucaena leucocephala, Sesbania grandiflora, situation analysis, outreach strategy.

\section{Introduction}

Forage tree legumes (FTL) have existed in the Eastern Indonesian landscape since colonial traders introduced several species in the late 1800 s. A specific effort was made to establish leucaena (Leucaena leucocephala) and sesbania (Sesbania grandiflora) for use as forage for cattle fattening at Amarasi in East Nusa Tenggara Province and Central Lombok in West Nusa Tenggara, in the 1970s (Yuksel et al. 1999; Dahlanuddin and Shelton 2005). Their spread within these provinces as potential forage to intensify cattle fattening systems, however, has been slow, if not stagnant. In preparation for intensified efforts to encourage farmers in East and West Nusa Tenggara to grow and use FTLs for cattle fattening, we asked the question why successful FTL feeding practices by some communities had not spread widely to adjacent areas within the provinces. A situation analysis study was conducted in 2011/12 in East and West Nusa Tenggara Provinces; it aimed at identifying the barriers to and opportunities for FTL use in smallholder cattle fattening systems. This paper describes the methodology of this study, its main findings and the implications for follow-up expansion of FTL innovations.

\section{Methodology}

The study sites were selected based on a set of criteria, including cattle population, ownership and management system, land ownership by farmers, current use or potential of FTLs, and suitability and accessibility of the villages for

Correspondence: E. van de Fliert, The University of Queensland, Centre for Communication and Social Change, St Lucia, Qld 4072, Australia. Email: e.vandefliert@uq.edu.au follow-up activities. The study looked at locations where leucaena and sesbania were already being intensively used for cattle fattening but where farmer practices can be improved, and where FTL use is limited. A total of 34 hamlets in 12 sub-districts in 6 districts across the 2 provinces were visited by study teams for 3 days each, during which a range of data collection methods were conducted. These included a transect walk with participatory mapping, observations and informal interviews (Figure 1), focus groups with male and female farmers (Figure 2), and

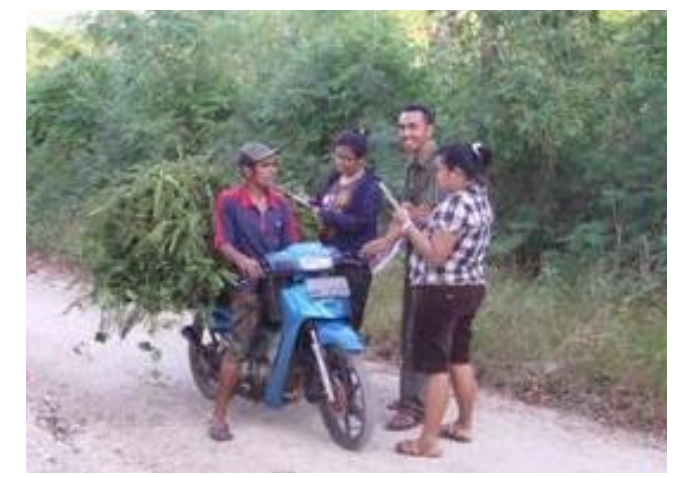

Figure 1. Informal interview during transect walks

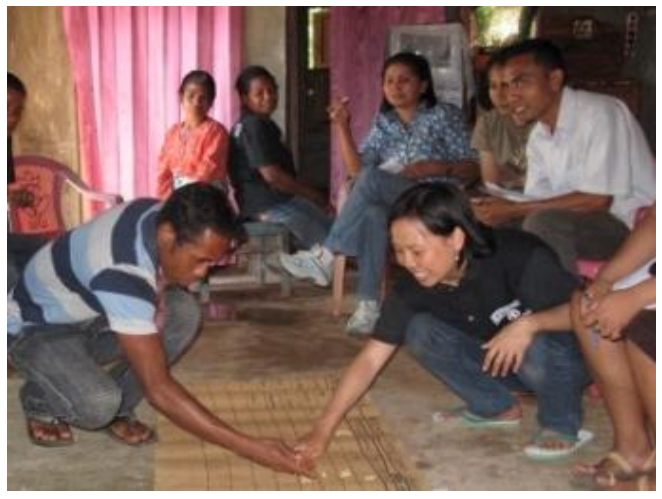

Figure 2. Focus group discussion. 
household interviews with 9-10 selected farmers per hamlet (Figure 3). The study provided detailed profiles of each of the locations, and a general understanding of farmers' current cattle management practices and their perceptions on the use of FTLs as cattle feed.

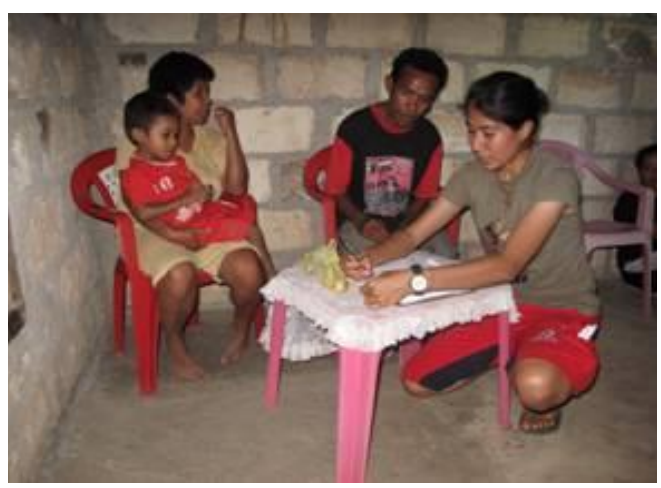

Figure 3. In-depth household interview

\section{Results and Discussion}

Barriers to adoption of forage tree legume innovations that were identified included the following:

\section{Leucaena systems (West Timor, Sumba, Sumbawa)}

- Where large areas of communal grazing lands are available, farmers do not see a need to allocate resources and labor to tether or pen cattle and feed by cut-and-carry methods. Families that own cattle and have the capacity to fatten tend to have a relatively large number of animals and prefer grazing over a cut-and-carry system, for which they do not have sufficient labor.

- In some areas, especially West Timor, farmers consider it is safer to let cattle graze on communal land than to tether or pen them, as theft tends to happen in built-up areas.

- There is a perception that newly established forage plots will be damaged by free-grazing animals, if the whole community does not participate in penning or tethering practices.

- Previously introduced varieties of leucaena are prone to psyllid infestation.

\section{Sesbania systems (Lombok)}

- Farmers do not have enough land to plant (more) sesbania trees. Where sesbania trees are planted on the paddy bunds, farmers feel they cannot increase their density, as there are already many trees and other fodder crops on the bunds.
- Many farmers believe that the sesbania trees on the bunds disrupt the development of the main crop in the paddy field by shading. In areas in Lombok with very narrow bunds, farmers fear (and have experienced) that sesbania roots can damage the bunds or cause water leakage.

\section{Both systems}

- FTL trees are not always available in the area, or not in sufficient amounts for intensive feeding, while other fodders such as grass are in abundance.

- Farmers lack knowledge and skills regarding tree establishment and have no access to FTL seed sources. Farmers tend to have limited knowledge on the feeding/nutritional requirements of cattle and how to match these with the nutritional value of different forages. There are many misconceptions among farmers about the nutritional value of FTLs and their side effects on cattle and feed preferences.

- In many cases, the price received for cattle at sale is not determined by the actual live weight but on an estimation by the trader. The limited bargaining power of the farmers provides a negative incentive for achieving maximum live weight of the animals. Many farmers tend to sell their cattle below the optimum sale weight due to lack of capital. This situation is unfavorable to the adoption of good feeding practices.

\section{Opportunities identified for the introduction and intensified use of FTLs}

- There is ample land available that can be allocated to FTLs, especially in areas where forage production systems are underdeveloped (Timor, Sumba and Sumbawa). Farmers have shown a willingness to make use of available land to integrate FTLs into their cropping and cattle feeding systems.

- A psyllid-tolerant variety of leucaena (cv. Tarramba) is now available in Eastern Indonesia and seems to be thriving under local conditions. Some farmers produce and sell FTL seed, while others market FTL foliage as forage to other farmers and perceive this to be a lucrative business.

- Areas where FTL plots were established have attracted participation from Department of Livestock cattle distribution schemes for farmers. Local village governments expressed a willingness to introduce village regulations to limit free grazing of animals and hence provide more favorable conditions for FTL plots to establish. 


\section{Conclusions}

While initial barriers to and opportunities for the adoption of leucaena and sesbania innovations were identified and formed the design of an outreach strategy, continuing follow-up assessment is needed in order to understand how increased knowledge of and access to FTL innovations influence farmers' perceptions and practices.

To overcome barriers to the implementation of FTL innovations and capitalize on existing opportunities, an effective outreach strategy would need to address perceptions, access and regulations. Perceptions can be influenced by providing information and experiences to farmers that alter their attitudes and improve their knowledge, skills and practices. This can be in the form of exchange visits, demonstration trials, information media, practice-based training and dialogue. Access relates to agricultural inputs, such as high quality FTL seed, advisory and credit services and land availability. Regulations may be required in some locations to support collective action. Such an outreach strategy is comprehensive and long-term, involves multiple stakeholders, and requires all elements to be aligned to overcome the diverse set of barriers and utilize existing assets.

\section{Acknowledgments}

The support of ACIAR is gratefully acknowledged.

\section{References}

Dahlanuddin; Shelton M. 2005. Sesbania grandiflora: A successful tree legume in Lombok, Indonesia. Tropical Grasslands 39:217.

Yuksel N; Aoetpah A; Imo. 1999. The Amarasi model - An example of indigenous natural resource management in $\mathrm{Ti}$ mor, Indonesia. Indigenous Fallow Management Network, Occasional Paper 1999/1, ICRAF Southeast Asian Regional Research Programme, Bogor, Indonesia.

\section{cc)(i) (2)}

Tropical Grasslands-Forrajes Tropicales is an open-access journal published by Centro Internacional de Agricultura Tropical (CIAT). This work is licensed under a Creative Commons Attribution-NonCommercial-ShareAlike 3.0 Unported License. To view a copy of this license, visit http://creativecommons.org/licenses/by-nc-sa/3.0/ 
Hau DK; Panjaitan T; Nulik J; Dahlanuddin; Van De Fliert E. 2014. Barriers to and opportunities for the use of forage tree legumes in smallholder cattle fattening systems in Eastern Indonesia. Tropical Grasslands Forrajes Tropicales 2:79-81.

DOI: $\underline{10.17138 / \mathrm{TGFT}(2) 79-81}$

This paper was presented at the $22^{\text {nd }}$ International Grassland Congress, Sydney, Australia, 15-19 September 2013. Its publication in Tropical Grasslands - Forrajes Tropicales is the result of a co-publication agreement with the IGC Continuing Committee. Except for adjustments to the journal's style and format, the text is essentially the same as that published in: Michalk LD; Millar GD; Badgery WB; Broadfoot KM, eds. 2013. Revitalising Grasslands to Sustain our Communities. Proceedings of the $22^{\text {nd }}$ International Grassland Congress, Sydney, Australia, 2013. New South Wales Department of Primary Industries, Orange, NSW, Australia. p. 1890-1891. 